\title{
A new troodontid theropod from the Late Cretaceous of central China, and the radiation of Asian troodontids
}

Junchang Lü, Li Xu, Yongqing Liu, Xingliao Zhang, Songhai Jia, and Qiang Ji Acta Palaeontologica Polonica 55 (3), 2010: 381-388 doi: http://dx.doi.org/10.4202/app.2009.0047

A new troodontid dinosaur, Xixiasaurus henanensis gen. et sp. nov., from the Upper Cretaceous Majiacun Formation of the Xixia Basin, Henan Province, is erected, based on a partial skull. It is characterized by bearing 22 maxillary teeth, a distinct opening on the lateral surface of the base of nasal process of the premaxilla, the rostral end of the upper jaw forming a tapered U-shape, and the mandibular symphyseal region slightly inflected medially. Xixiasaurus is most closely related to the Mongolian Byronosaurus among troodontids. Byronosaurus, Urbacodon, and Xixiasaurus may form a new clade, suggesting an endemic radiation of troodontids across Asia, including multiple taxa without dental serrations. The discovery of Xixiasaurus in the Xixia Basin may imply that the Xixiasaurus-bearing Majiacun Formation is Campanian in age.

Key words: Theropoda, Troodontidae, Xixiasaurus, Late Cretaceous, Henan Province, China.

Juanchang Lü [Lujc2008@126.com], Yongquing Liu [liu_cags@126.com], and Qiang Ji [jirod@cags.net.cn], Institute of Geology, Chinese Academy of Geological

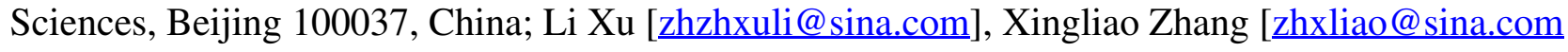
], and Songhai Jia [jiasonghai@163.com], Henan Geological Museum, Zhengzhou 450016, Henan Province, China.

This is an open-access article distributed under the terms of the Creative Commons Attribution License (for details please see creativecommons.org), which permits unrestricted use, distribution, and reproduction in any medium, provided the original author and source are credited. 